\title{
Keefektifan Konseling Modifikasi Kognitif Perilaku untuk Menurunkan Stres Akademik Siswa
}

\author{
Yeni Karneli ${ }^{1}$, Ardimen ${ }^{2}$, Netrawati ${ }^{3}$ \\ Jurusan BK Fakultas Ilmu Pendidikan, Universitas Negeri Padang ${ }^{1}$, \\ Jurusan BK Fakultas Ilmu Tarbiyah dan Keguruan, IAIN Batusangkar ${ }^{2}$, \\ Jurusan BK Fakultas Ilmu Pendidikan, Universitas Negeri Padang ${ }^{3}$ \\ Email: yenikarneli.unp@gmail.com ${ }^{1}$, ardimen@iainbatusangkar.ac.id ${ }^{2}$, \\ netrawati.unp07@fip.unp.ac.id ${ }^{3}$
}

\begin{abstract}
:
This research is motivated by the high level of academic stress students have. by showing the behavior of avoiding lessons, such as often leaving class when school hours, skipping lessons, not doing school work, ignoring school assignments. The purpose of this study was to determine the effectiveness of the cognitive behavioral modification counseling approach (KMKP) in reducing students' academic stress. The method used was quantitative with the Quasi experimental research design. The design form used was the pretest-posttest control group design. Data analysis using non-parametric statistics, namely Wilcoxon Signed Ranks Test. The results showed an effective behavioral modification counseling approach to reduce students' academic stress. This is evidenced because the behavioral cognitive modification counseling approach places great emphasis on changing the internal dialogue of the counselee.
\end{abstract}

Keyword: academic stress, cognitive behavioral modification counseling

Received February 03 , 2019; Revised March 05, 2019; Accepted April 01, 2019

How to Cite: Karneli, Y., Ardimen, \& Netrawati. (2019). Keefektifan Konseling Modifikasi Kognitif Perilaku untuk Menurunkan Stres Akademik Siswa. JKI (Jurnal Konseling Indonesia), 4(2), 42-47.

This is an open access article distributed under the Creative Commons 4.0 Attribution License, which permits unrestricted use, distribution, and reproduction in any medium, provided the original work is properly cited. ๑2019 by author and Universitas Kanjuruhan Malang.

\section{PENDAHULUAN}

Stres merupakan tekanan yang terjadi dalam kehidupan yang apabila tidak dikelola dengan baik akan menimbulkan berbagai masalah. Untuk itu stres perlu mendapatkan perhatian (Agolla, 2009). Tanggapan seseorang terhadap stres tergantung apakah peristiwa itu dinilai sebagai tantangan atau ancaman. Suatu peristiwa yang dinilai sebagai sebuah tantangan dapat menjadi motivasi dan dapat meningkatkan kinerja tugas, sementara sebuah peristiwa yang dianggap sebagai suatu ancaman akan mengakibatkan seseorang menjadi depresi, disfungsi sosial dan bahkan niat bunuh diri (Lazarus \& Folkman, 1984), dan stres itu bisa berdampak positif atau negatif jika tidak dikelola dengan baik (Stevenson \& Harper, 2006).

Stres yang terjadi dalam dunia pendidikan disebut stres akademik yaitu suatu kondisi atau keadaan individu yang mengalami tekanan sebagai hasil persepsi dan penilaian tentang stresor akademik, yang berhubungan dengan ilmu pengetahuan dan pendidikan (Govaerts \& Grégoire, 2004). Stres akademik merupakan respon siswa terhadap berbagai tuntutan yang bersumber dari proses belajar mengajar seperti (1) 
tuntutan naik kelas, (2) menyelesaikan banyak tugas, (3) mendapatkan nilai ulangan yang tinggi, (4) keputusan menentukan jurusan, (5) kecemasan menghadapi ujian dan (6) tuntutan untuk dapat mengatur waktu belajar (Kariv et al., 2005). Studi pendahuluan selama Januari 2016 terhadap siswa SMK N 9 Padang menggambarkan tingginya tingkat stres akademik yang dimiliki siswa dengan rincian sebagai berikut: 40,74\% siswa merasa terbebani dengan keharusan mempertahankan peringkat sekolah; 62,96\% siswa merasa cemas menghadapi ujian semester; $82,72 \%$ siswa merasa takut mendapat nilai ulangan yang jelek; $80,25 \%$ siswa merasa bingung menyelesaikan PR yang terlalu banyak dan 50,62\% siswa merasa letih mengikuti perpanjangan waktu belajar di sekolah.

Data di atas menggambarkan bahwa tingginya tingkat stres akademik yang dimiliki siswa SMK N 9 Padang. Siswa dengan stres akademik tinggi akan menunjukkan tingkah laku menghindari pelajaran, seperti sering meningalkan kelas ketika jam pelajaran, membolos, tidak mengerjakan tugas sekolah, mengabaikan tugas-tugas sekolah. Mereka memiliki kecenderungan untuk mengerjakan sesuatu yang lebih menyenangkan, menunda-nunda penyelesaian tugas sekolah, tidak peduli dengan tugas dan beban belajar yang harus dihadapi, menyendiri, takut bertemu guru, benci dengan guru-guru tertentu, malas sekolah, penyalahgunaan obat-obat dan alkohol, dan terlibat dalam kegiatan mencari kesenangan secara berlebih-lebihan dan beresiko tinggi (Kariv et al., 2005); (Katz \& Rice, 2002); (Jordaan et al., 2007). Stres akademik muncul karena adanya tekanan-tekanan untuk menunjukkan prestasi dan keunggulan dalam kondisi persaingan akademik yang semakin meningkat sehingga peserta didik semakin terbebani oleh berbagai tekanan dan tuntutan (Agolla, 2009). Stres akademik muncul ketika harapan untuk meraih prestasi meningkat, baik dari orang tua, guru maupun teman sebaya, dimana harapan tersebut tidak sesuai dengan kemampuan yang siswa miliki sehingga menimbulkan tekanan psikologis yang mempengaruhi pencapaian prestasi belajar di sekolah.

Penyebab stres akademik siswa adalah adanya tuntutan pencapaian prestasi akademik yang lebih tinggi yang tidak sesuai dengan kemampuan siswa misalnya mendapatkan nilai tinggi, menyelesaikan semua tugas dengan baik dan dapat masuk perguruan tinggi nantinya. Sumber stres akademik itu berasal dari ujian, persaingan nilai, jadwal sekolah yang padat, terlalu banyaknya pekerjaan rumah dan beban pelajaran yang harus dipelajari sementara sedikitnya waktu yang dimilik. Namun stres ini tergantung bagaimana penilaian kognitif siswa tersebut dalam menilai dan menginterpretasikan stresor. (Lazarus \& Folkman, 1984) penilaian kognitif (cognitive appraisal) adalah istilah yang digunakan untuk menggambarkan interpretasi individu terhadap kejadian-kejadian dalam hidup mereka sebagai sesuatu yang berbahaya, mengancam, atau menantang dan keyakinan mereka apakah mereka memiliki kemampuan untuk menghadapi suatu kejadian dengan efektif.

Stres akademik yang sering terjadi pada siswa berupa kecemasan menghadapi ujian, takut mendapat nilai ulangan yang jelek, bingung menyelesaikan PR yang terlalu banyak dan letih mengikuti perpanjangan waktu belajar di sekolah. Tekanan untuk berprestasi baik dalam ujian atau tes dan waktu yang dialokasikan membuat lingkungan akademik sangat menegangkan (Erkutlu \& Chafra, 2006). Efek negatif dari terjadinya stress akademik dapat mempengaruhi keefektifan performan siswa dalam melakukan sebuah tugas, mengganggu fungsi kognitif, menyebabkan gangguan psikologis dan fisik. Keadaan tersebut berpotensi menurunkan prestasi siswa dalam bidang akademik. Selain itu, stress akademik berhubungan langsung dengan prestasi yang rendah di sekolah, (Agolla, 2009) mengemukakan stres akademik yang dialami siswa terus menerus akan mengakibatkan penurunan daya tahan tubuh siswa sehingga mudah mengalami sakit. Penyebab stres akademik dikalangan siswa adalah mata pelajaran yang padat, sumber daya yang tidak memadai dalam bidang akademik (Awino \& Agolla, 2008). Tekanan untuk berprestasi baik dalam ujian atau tes dan waktu yang dialokasikan membuat lingkungan akademik sangat menegangkan (Erkutlu \& Chafra, 2006).

Dalam proses konseling, tingginya stres akademik yang dimiliki siswa disebabkan oleh faktor kognitif untuk itu proses bantuan akan lebih baik difokuskan pada aspek-aspek kognitif positif dari pada menyoroti sisi kognitif negatifnya. Menurut (Beck, 1976) perubahan perilaku dan afeksi terjadi melalui perubahan kognisi. Untuk itu intervensi yang digunakan harus melibatkan proses kognitif dalam rangka mengubah perilaku klien. Paradigma konseling yang bertujuan membantu klien mengubah perilaku dengan memfokuskan pada kemampuan kognitif dan perilaku klien, antara lain pendekatan konseling Rational Emotive Behavior Therapy (REBT) oleh Ellis, Cognitive Therapy (CT) oleh Beck, dan Modifikasi kognitif perilaku (KMKP) dari Meichenbaum. Ketiga pendekatan terapi tersebut sama-sama berasumsi bahwa terjadinya problem akademik seperti stres akademik disebabkan oleh cara berpikir yang maladaptif. Diantara ketiga pendekatan tersebut, pendekatan modifikasi kognitif perilaku dari Meichenbaum memiliki perbedaan dengan kedua pendekatan lain yaitu REBT-nya Ellis dan CT-nya Beck. Pendekatan konseling REBT dan CT lebih menekankan konfrontasi dengan pikiran-pikiran maladaptif dan penyingkapan pemikiran yang irrasional dilakukan lebih langsung dan konfrontatif. Modifikasi kognitif perilaku (KMKP) lebih menekankan pada konseling membelajarkan diri sendiri yang menolong klien menjadi lebih sadar akan kata- 
kata yang diarahkan pada dirinya sendiri, sehingga mereka bisa menangani secara lebih efektif masalah mereka. Selain itu, pendekatan konseling Modifikasi kognitif perilaku (KMKP) menekankan pada keaktifan klien, waktunya singkat dan disusun secara terbuka, sehingga sangat sesuai untuk diterapkan pada remaja di sekolah.

Arikel ini membahas keefektifan konseling dengan pendekatan modifikasi kognitif perilaku (KMKP) dari Meichenbaum untuk menurunkan stres akademik siswa. Menurut Kazdin (Dobson, 2001) istilah cognitive behavior modificaction (modifikasi kognitif perilaku) mengarahkan tujuan konseling untuk mengubah perilaku maladaptif yang nampak dengan cara memodifikasi cara berfikir, interpretasi, asumsi, dan strategi merespon sesuatu. Meichenbaum (Dobson, 2001) mengemukakan bahwa untuk mengubah perilaku mal-adaptif yang tidak nampak dapat dilakukan seperti cara mengubah perilaku yang nampak. Perubahan perilaku terjadi melalui suatu urutan proses mediasi yang melibatkan interaksi self-talk, struktur kognitif dan perilaku.

Hasil penelitian (Bentley, 2002) menunjukkan pendekatan konseling modifikasi kognitif perilaku (KMKP) efektif untuk menurunkan stres akademik siswa, memperbaiki perilaku yang tepat dan meningkatkan kesuksesan akademik terutama ketika siswa akan menghadapi ujian dan menghadapi mata pelajaran tertentu. Menurut (Cormier et al., 2003) dari beberapa teknik yang ada dalam pendekatan konseling modifikasi kognitif perilaku (KMKP) diantaranya adalah teknik relaksasi, restrukturisasi kognitif, time manajement, problem solving skills, self-intruction dan lain-lain telah teruji efektif digunakan pada berbagai macam populasi, misalnya anak yang hiperaktif, mengontrol kemarahan, membantu siswa yang mengalami learning disability, menurunkan stres akademik, mengurangi kecemasan terhadap ujian dan lain-lain.

Penelitian yang dilakukan oleh Meichenbaum (Corey, 2011) menunjukkan kesuksesan konseling dengan pendekatan konseling modifikasi kognitif perilaku (KMKP) dalam merestrukturisasi kognitif manakala diaplikasikan pada problema akademik, termasuk stres akademik. Kesuksesan pengaplikasian pendekatan konseling modifikasi kognitif perilaku (KMKP) dalam merestrukturisasi kognitif yang maladaptif, membuktikan pendekatan konseling modifikasi kognitif perilaku (KMKP) efektif untuk menurunkan stres akademik.

Beberapa alasan di atas mengokohkan pendekatan konseling modifikasi kognitif perilaku (KMKP) sebagai modus untuk membantu menurunkan tingkat stres akademik yang dialami siswa. Kemudahan dalam prosedur yang digunakan serta tidak banyak menyita waktu berinteraksi antara konselor dengan klien, menjadi alasan lain untuk melaksanakan pendekatan konseling modifikasi kognitif perilaku (KMKP). Adapun tahapan konseling dengan KMKP terdiri atas tahapan-tahapan berikut: Pertama, observasi diri. Di awal konseling klien diminta untuk mendengarkan dialog internal dalam diri mereka dan mengenali karakteristik pernyataan negatif yang ada. Proses ini melibatkan kegiatan meningkatkan sensitivitas terhadap pikiran, perasaan, perbuatan, reaksi fisiologis dan pola reaksi terhadap orang lain. Kedua, membuat dialog internal baru. Setelah klien belajar mengenali tingkah laku maladaptifnya, mereka mulai mencari kesempatan untuk mengembangkan alternatif tingkah laku adaptif, dengan cara mengubah dialog internal dalam diri mereka. Dialog internal yang baru diharapkan dapat menghasilkan tingkah laku baru, yang sebaliknya akan memberikan dampak terhadap struktur kognisi klien,dan ketiga, belajar keterampilan baru. Klien kemudian belajar teknik mengatasi masalah yang secara praktis dapat diterapkan dalam kehidupan sehari-hari. Pada saat yang sama, klien diharapkan untuk tetap memusatkan perhatiannya kepada tugas membuat pernyataan baru dan mengamati perbedaan hasilnya.

\section{METODE PENELITIAN}

Penelitian ini adalah penelitian kuantitatif dengan rancangan penelitian Quasi experiment (Tuckman, 1999); (Ary et al., 2002). Bentuk desain yang digunakan dalam penelitian ini adalah pretest-postest control group design. Penentuan sampel dilakukan dengan teknik cluster sampling, dengan menentukan target kelas sampel yaitu kelas X SMK N 9 Padang. Pengumpulan data dilakukan dengan menggunakan skala stres akademik, lembar refleksi diri, pedoman observasi dan lembar tugas siswa. Analisis data dengan menggunakan statistik non parametrik yaitu Wilcoxon Signed Ranks Test.

\section{HASIL}

Penelitian ini menggunakan pendekatan konseling modifikasi kognitif perilaku (KMKP) untuk menurunkan tingkat stres akademik siswa SMK N 9 Padang. Proses penelitian ini kolaborasi peneliti dengan konselor SMK N 9 Padang. Penelitian ini dilakukan pada 20 orang subjek (siswa) yang mengalami masalah 
stres akademik yang telah terjaring melalui skala stres akademik. Dari 20 orang subjek, kemudian dibagi secara random ke dalam dua kelompok yaitu 10 orang kelompok eksperimen (subjek yang mendapat perlakuan pendekatan konseling modifikasi kognitif perulaku (KMKP)) dan 10 orang kelompok kontrol (subjek yang menggunakan usually counseling/tanpa KMKP). Lebih jelasnya dapat dilihat pada tabel 1 berikut ini:

Tabel 1. Kondisi Stres Akademik Masing-masing Siswa Kelompok Eksperimen dan Kelompok Kontrol pada Pretest dan Posttest

\begin{tabular}{|c|c|c|c|c|c|c|c|c|c|}
\hline \multicolumn{5}{|c|}{ Eksperimen } & \multicolumn{5}{|c|}{ Kontrol } \\
\hline \multirow{2}{*}{$\begin{array}{l}\text { Kode } \\
\text { Siswa }\end{array}$} & \multicolumn{2}{|c|}{ Pretest } & \multicolumn{2}{|c|}{ Posttest } & \multirow{2}{*}{$\begin{array}{l}\text { Kode } \\
\text { Siswa }\end{array}$} & \multicolumn{2}{|c|}{ Prestest } & \multicolumn{2}{|c|}{ Posttest } \\
\hline & Skor & Kategori & Skor & Kategori & & Skor & Kategori & Skor & Kategori \\
\hline EN & 76 & Tinggi & 106 & Sedang & SK & 77 & Tinggi & 80 & Tinggi \\
\hline AN & 72 & Tinggi & 100 & Sedang & MS & 110 & Sedang & 112 & Sedang \\
\hline RT & 74 & Tinggi & 99 & Sedang & NR & 74 & Tinggi & 83 & Tinggi \\
\hline MR & 76 & Tinggi & 116 & Rendah & WY & 75 & Tinggi & 86 & Sedang \\
\hline GT & 75 & Tinggi & 121 & Rendah & DR & 76 & Tinggi & 75 & Tinggi \\
\hline FM & 104 & Sedang & 114 & Rendah & WD & 106 & Sedang & 105 & Sedang \\
\hline $\mathrm{TF}$ & 75 & Tinggi & 113 & Rendah & ER & 76 & Tinggi & 90 & Sedang \\
\hline RK & 122 & Rendah & 125 & Rendah & EN & 122 & Rendah & 121 & Rendah \\
\hline MW & 123 & Rendah & 129 & Rendah & EL & 125 & Rendah & 123 & Rendah \\
\hline $\mathrm{AR}$ & 108 & Sedang & 122 & Rendah & YN & 74 & Tinggi & 85 & Tinggi \\
\hline
\end{tabular}

Berdasarkan tabel 1, dapat dilihat perbedaan kondisi stres akademik masing-masing siswa kelompok eksperimen dan kelompok kontrol pada pretest dan posttest. Pada kelompok eksperimen setiap siswa mengalami peningkatan skor, artinya terjadi pengurangan stres akademik pada setiap siswa. Sedangkan pada kelompok kontrol hanya beberapa siswa yang meningkat skornya, dengan peningkatan kecil dan ada juga siswa yang mengalami penurunan skor, dalam artian mengalami peningkatan stres akademik.

Berdasarkan uraian terdahulu, untuk melihat lebih jelas kondisi stres akademik siswa berdasarkan indikator stres akademik pada kelompok eksperimen dan kelompok kontrol pada prestest dan posttest, dapat disajikan pada tabel berikut.

Pengujian hipotesis dilakukan dengan menggunakan statistik non parametrik dengan Wilcoxon Signed Ranks Test. Berdasarkan hasil uji Wilcoxon Signed Ranks Test, terdapat perbedaan nyata tingkat stres akademik siswa SMK N 9 Padang antara kelompok eksperimen dan kelompok kontrol sesudah perlakuan pendekatan konseling modifikasi kognitif perilaku (KMKP). Hal ini dapat dilihat dari perbedaan tingkat stres akademik siswa, dimana setelah pelatihan pendekatan konseling modifikasi kognitif perilaku (KMKP) terjadi penurunan tingkat stres akademik. Kesimpulan uji hipotesis, tingkatan stres akademik siswa SMK N 9 Padang pada kelompok eksperimen sesudah perlakuan pendekatan konseling modifikasi kognitif perilaku (KMKP) mengalami penurunan yang signifikan dibandingkan dengan siswa pada kelompok kontrol. Berdasarkan hasil tersebut, menunjukkan bahwa ada perbedaan yang signifikan antara konseli yang mendapat intervensi pendekatan konseling modifikasi kognitif perilaku (KMKP) dan konseli yang mendapat usually counseling. Selain itu perbedaan juga ditunjukkan melalui perolehan skor skala stres akademik konseli yang diberi intervensi pendekatan konseling modifikasi kognitif perilaku (KMKP) lebih rendah pada saat pemberian post-test. Dengan demikian, hasil penelitian ini menunjukkan bahwa pendekatan konseling modifikasi kognitif perilaku (KMKP) efektif untuk menurunkan stres akademik siswa SMK.

\section{PEMBAHASAN}

Hasil penelitian ini mendukung hasil penelitian sebelumnya yang dilakukan (Farida, 2008) tentang keefektifan pendekatan Cognitive Behavior Modivication untuk mengelola stres belajar siswa di SMPI Sabilillah Kota Malang. Mencermati hasil penelitian di atas, maka dalam penelitian ini dapat ditegaskan kembali bahwa pendekatan konseling modifikasi kognitif perilaku (KMKP) efektif untuk menurunkan stres akademik siswa. 
Berdasarkan hasil penelitian yang dikemukakan di atas, dapat dijadikan bukti (evidence) yang kuat untuk dilakukan penelitian ini sebagai upaya untuk menurunkan stres akademik siswa melalui intervensi konseling kognitif perilaku (KMKP). Dalam penelitian ini, yang menjadi salah satu faktor keberhasilan pendekatan konseling modifikasi kognitif perilaku (KMKP) untuk menurunkan stres akademik adalah karena lebih menekankan pada konseling membelajarkan diri sendiri. Proses konselingnya terdiri atas melatih konseli memodifikasi pembelajaran yang diberikan kepada dirinya sendiri sehingga mereka bisa menangani masalah yang mereka hadapi lebih efektif. Selain itu pendekatan konseling modifikasi kognitif perilaku (KMKP) menekankan pada keaktifan klien, waktunya singkat, dan disusun secara terbuka, sehingga sesuai untuk diterapkan pada siswa di sekolah.

Pendekatan konseling modifikasi kognitif perilaku (KMKP) merupakan konseling yang menggabungkan terapi kognitif dan bentuk modifikasi perilaku Meichenbaum (Kanfer \& Goldstein, 1991). Individu yang akan bertindak, didahului adanya proses berfikir, sehingga untuk mengubah suatu perilaku yang tidak adaptif akibat stres akademik yang dialaminya, harus terlebih dahulu memahami aspek-aspek yang berada dalam pengalaman kognitif dan usaha untuk membangun perilaku adaptif melalui mempelajari keterampilan-keterampilan yang terdapat pada terapi kognitif behavior dan mengaplikasikannya pada kehidupan sehari-hari (P. H. Meichenbaum et al., 1975). Jadi pendekatan pendekatan konseling modifikasi kognitif perilaku (KMKP) memandang stres akademik sebagai suatu yang alami yang terjadi pada siswa, sehingga dengan mengajarkan sejumlah keterampilan dalam menurunkan stres akademik akan membantu siswa dalam mengembangkan kognisi, emosi dan perilakunya ke arah yang positif.

Stres akademik timbul dari penilaian kognitif mengenai kemampuan yang dimilikinya, yang terdiri komponen-komponen seperti kognitif, emosi dan perilaku yang terbentuk dari stimulus-kognisi-respon (SKR) yang saling berkait dalam otak manusia. Proses kognitif akan menjadi faktor penentu dalam menjelaskan bagaimana manusia berpikir, merasa dan bertindak (D. Meichenbaum et al., 2007); (Oemarjoedi, 2003). Hal ini memiliki makna bahwa stres akademik muncul dari penilaian kognitif yang disebabkan oleh cara berpikir siswa yang mengalami penyimpangan (mal-adaptif). Stres akademik muncul ketika harapan untuk pencapaian prestasi belajar meningkat, baik dari orang tua, guru, ataupun teman sebaya dan harapan tersebut tidak sesuai dengan kemampuan siswa (Shahmohammadi, 2011). Persepsi siswa yang mengganggap tuntutan belajar sebagai beban berakibat pada perasaan negatif berupa tidak siap dan terancam kenyamanan dalam menjalani kegiatan belajar baik di sekolah maupun di rumah.

Pendekatan konseling modifikasi kognitif perilaku (KMKP) berupaya untuk memodifikasi pikiran, emosi dan perilaku siswa secara mandiri untuk mengubah pemikiran yang mal-adaptif dengan mengaplikasikan teknik time management yang telah diajarkan konselor di sekolah dalam kehidupan sehari-hari. Keterampilan baru yang diberikan konselor dalam pendekatan konseling modifikasi kognitif perilaku (KMKP) akan menjadi sumber kekuatan bagi siswa dalam menurunkan stres akademiknya (D. Meichenbaum et al., 2007).

\section{SIMPULAN DAN SARAN}

Berdasarkan pengujian hipotesis dengan menggunakan Uji Wilcoxon Signed Ranks Test, terdapat perbedaan tingkat stres akademik siswa SMK N 9 Padang antara kelompok eksperimen dan kelompok kontrol sesudah perlakuan pendekatan konseling modifikasi kognitif perilaku (KMKP). Dengan demikian, hasil penelitian ini menunjukkan bahwa pendekatan konseling modifikasi kognitif perilaku (KMKP) efektif untuk menurunkan stres akademik siswa SMK.

Mencermati hasil uji hipotesis di atas, maka dapat disimpulkan bahwa hasil penelitian ini dapat menjawab rumusan masalah yaitu pendekatan konseling modifikasi perilaku (KMKP) efektif untuk menurunkan stres akademik siswa SMK.. Hasil penelitian ini juga berguna untuk mengubah pola pikir, emosi dan perilaku siswa sehingga bisa mengelola stres akademik yang dialaminya.

\section{DAFTAR RUJUKAN}

Agolla, J. E. (2009). Occupational stress among police officers: the case of Botswana police service. Research Journal of Business Management, 2(1), 25-35.

Ary, D., Jacobs, Lc., Razavieh, A., \& Sorensen, C. (2002). Introduction to research in education 6 th ed. Belmont, CA: Wadsworth.

Awino, J. O., \& Agolla, J. E. (2008). A quest for sustainable quality assurance measurement for universities: Case study of the University of Botswana. Educational Research and Reviews, 3(6), 213.

Beck, A. T. (1976). Cognitive theory and the emotional disorders. New York: International Universities Press. 
Bentley, J. K. C. (2002). Improving behavior and self-efficacy beliefs in the classroom through cognitivebehavior modification. Retrieved January 26, 2009, from http://www.findarticles.com

Corey, G. (2011). Theory and Practice of Counseling and Psychotherapy. Belmot, CA: Brooks/Cole.

Cormier, L., Reid, K., Kwan, L., \& Litwin, M. S. (2003). Screening behavior in brothers and sons of men with prostate cancer. The Journal of Urology, 169(5), 1715-1719.

Dobson, K. S. (2001). Handbook of Cognitive-Behavioral Therapies. London: Guilford Press.

Erkutlu, H. V, \& Chafra, J. (2006). Relationship between leadership power bases and job stress of subordinates: example from boutique hotels. Management Research News, 29(5), 285-297.

Farida, A. (2008). Keefektifan Pendekatan Cognitive Behavior Modivication untuk Mengelola Stres Belajar Siswa di SMPI Sabilillah Kota Malang. Universitas Negeri Malang.

Govaerts, S., \& Grégoire, J. (2004). Stressful academic situations: study on appraisal variables in adolescence. Revue Européenne de Psychologie Appliquée/European Review of Applied Psychology, 54(4), 261-271.

Jordaan, I., Spangenberg, J. J., Watson, M. B., \& Fouchè, P. (2007). Emotional stress and coping strategies in South African clinical and counselling psychologists. South African Journal of Psychology, 37(4), 835-855.

Kanfer, F. H., \& Goldstein, A. P. (1991). Helping people change: A textbook of methods. Pergamon Press.

Kariv, D., Heiman, T., \& Zion, R. Le. (2005). Stressors, Stress and Coping in Dual-Demand Environments: The Case of Working 'Back to Schoolers.' Journal of Adult and Continuing Education, 11(1), 91110 .

Katz, J. E., \& Rice, R. E. (2002). Social consequences of Internet use: Access, involvement, and interaction. MIT press.

Lazarus, R. S., \& Folkman, S. (1984). Stress, appraisal, and coping. Springer publishing company.

Meichenbaum, D., Lehrer, P. M., Woolfolk, R. L., \& Sime, W. S. (2007). Principles and practice of stress management. Guilford Press: New York, NY, USA.

Meichenbaum, P. H., Kanfer, F. H., \& Goldstein, A. P. (1975). Helping people change. New York: Pergamon Press.

Oemarjoedi, A. K. (2003). Pendekatan cognitive behavior dalam psikoterapi. Jakarta: Kreativ Media.

Shahmohammadi, N. (2011). Students' coping with Stress at high school level particularly at 11th \& 12th grade. Procedia-Social and Behavioral Sciences, 30, 395-401.

Stevenson, A., \& Harper, S. (2006). Workplace stress and the student learning experience. Quality Assurance in Education, 14(2), 167-178.

Tuckman, B. W. (1999). Conducting education research. United State of America: Harcourt Brace \& Company. 